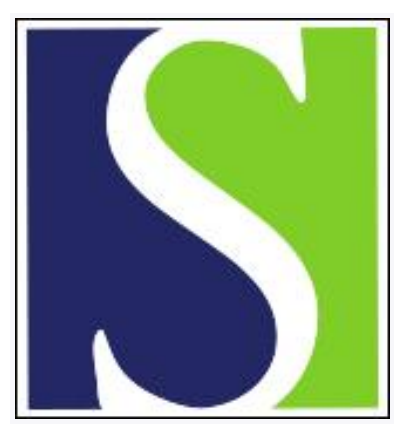

Scand J Work Environ Health 1989;15(1):69-74

https://doi.org/10.5271/sjweh.1880

Issue date: Feb 1989

Subjective symptoms and psychological performance of chlorine-alkali workers.

by Piikivi L, Hanninen $\mathrm{H}$

Affiliation: Oulu Health Centre, Division of Occupational Health, Oulu, Finland.

This article in PubMed: www.ncbi.nlm.nih.gov/pubmed/2922591

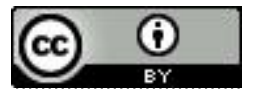




\title{
Subjective symptoms and psychological performance of chlorine-alkali workers
}

\author{
by Leena Piikivi, MD, ${ }^{1}$ Helena Hänninen, $\mathrm{PhL}^{2}$
}

\begin{abstract}
PIIKIVI L, HÄNNINEN H. Subjective symptoms and psychological performance of chlorine-alkali workers. Scand J Work Environ Health 1989;15:69-74. Subjective symptoms and psychological performances on a computer-administered test battery were studied among a group of 60 chlorine-alkali workers and their matched referents. The exposure time of the group exposed to inorganic mercury vapor had been about 14 years, and the estimated long-term average exposure had been about $25 \mu \mathrm{g} / \mathrm{m}^{3}$ of air. The exposed workers had an actual mercury concentration of 51.9 (SD 25.0, range $15-150$ ) $\mathrm{nmol} / \mathrm{l}$ in blood and 84.1 (SD 56.6, range $15-260$ ) $\mathrm{nmol} / \mathrm{l}$ in urine. Neither perceptual motor nor memory nor learning abilities of the mercury-exposed workers showed any disturbances in a comparison with the referents. However, the exposed group reported statistically significantly more memory disturbances than the referents. Strain caused by three-shift work was a possible cofactor for other increased subjective symptoms, namely, for sleep disorders, fatigue, and confusion.
\end{abstract}

Key terms: blood mercury, elemental mercury vapor, urinary mercury.

The central nervous system is the critical target organ during long-term exposure to organic mercury vapor (1). Initial symptoms in intoxications due to elemental mercury have ranged from atactic intention tremor to a bizarre constellation of mental changes (2). Nonspecific subjective symptoms such as fatigue, weakness, loss of memory, insomnia, and increased irritability have been characterized as micromercurialism in subjects exposed for long periods of time to low concentrations of mercury vapor $(3,4)$. In psychological tests disturbances of cognitive and psychomotor functions have been associated with low levels of mercury exposure (5-9). However, conflicting data have also been reported for workers at similar levels of exposure $(10,11)$.

The purpose of the present study was to discover whether exposure conditions of about $25 \mu \mathrm{g}$ of mercury $/ \mathrm{m}^{3}$ of air, as estimated by repeated analyses of blood mercury concentrations, had resulted in any measurable increase in subjective symptoms or disturbances on a psychological test battery.

\section{Materials and methods}

\section{Subjects and study design}

Subjective symptoms and performances on psychological tests were recorded by means of a cross-sectional design. The design was longitudinal for the exposure assessment, which was estimated from earlier blood mercury analyses.

\footnotetext{
1 Oulu Health Centre, Division of Occupational Health, Oulu, Finland.

2 Institute of Occupational Health, Helsinki, Finland.
}

Reprint requests to: Dr L Piikivi, Oulu Health Centre, PO Box 365, SF-90101 Oulu, Finland.
After exclusions the exposed group consisted of 60 men who had been exposed to elemental mercury vapor in a chlorine-alkali plant for at least five years. The exclusion criteria were neurological, psychiatric and metabolic diseases, abuse of alcohol, skull injuries, and hypertension checked from the records of the periodic health examinations performed twice a year, as well as from possible case records. Seven of the workers who fulfilled the exposure criterion were excluded from the study group. Four of them had chronic hypertension, and the others suffered from dipsomania (identified by the occupational health staff of the company). In addition, since 1972, seven other workers had been moved to unexposed tasks, two of them because of chronic respiratory disease and the others because of repeatedly increased concentrations of mercury in their blood. The turnover of personnel without known mercury-related problems could not be controlled. No cases of mercury intoxication had been diagnosed among the chlorine-alkali workers since the 1960s.

The mean age of the exposed group was 38.0 (SD 6.6 , range $26-56$ ) years. Their average exposure time was 13.7 (SD 5.5, range 5-28) years. The exposed workers had had general and vocational education for a mean of 10.0 (SD 2.6, range 3-15) years. One subgroup $(\mathrm{N}=37)$ had three-shift work with periods of four workdays and $2 \mathrm{~d}$ of rest. The other exposed workers $(\mathrm{N}=23)$ had regular daywork with periods of five workdays and $2 \mathrm{~d}$ of rest. The mean age was 38.7 (SD 7.2, range 26-56) years for the three-shift workers and 36.7 (SD 5.4, range 29-49) years for the day workers.

One referent, matched for age ( \pm 1 year), sex, vocational status, and length of education, was chosen for each exposed worker. The referents $(\mathrm{N}=60)$ were employed in mechanical woodprocessing plants. The exclusion criteria for the reference group were earlier oc- 
cupational exposure to known neurotoxic chemicals or a history of the same chronic diseases and injuries listed as exclusion criteria for the exposed group. Rejection was based on medical records and on the judgment of the occupational health staff of the employing company. The mean age of the referents was 38.2 (SD 6.6, range 28-55) years. Their general and vocational education had lasted for a mean of 9.4 (SD 1.8, range 6-14) years. All the referents had regular daywork.

\section{Examinations}

At 1300 the subjects came to the hospital where the examinations took place. Except for two of the referents, the dayshift workers had had five and the threeshift workers six workhours before their arrival. Only one subject was examined per day. Special attention was given to standardization of the timing and to adherence to a strict examination procedure. At the beginning of the examinations every subject was interviewed according to a fixed schedule covering medical and occupational history, present health status, and life style. Furthermore, a questionnaire that the subjects had filled out earlier on subjective symptoms was checked and completed if necessary. The interview was followed by a clinical examination and the administration of computer-administered psychological tests. All the interviews and clinical examinations were performed by one of the authors (LP). On the basis of the interviews and observations made in the clinical examinations, the health status of the subjects was judged to be good. The subjects did not report any current use of medicines affecting the central nervous system, and they had not consumed more alcohol than

Table 1. Applied psychological test battery, taken from the computer-administered neurobehavioural evaluation system of Baker \& Letz (14).

\begin{tabular}{|c|c|c|}
\hline Test & Functional domain & Test parameters \\
\hline \multicolumn{3}{|l|}{ Psychomotor tests } \\
\hline Finger Tapping & Motor speed & $\begin{array}{l}\text { Number of button } \\
\text { presses in } 10 \mathrm{~s}\end{array}$ \\
\hline $\begin{array}{l}\text { Continuous } \\
\text { Performance Test }\end{array}$ & Visuomotor speed & $\begin{array}{l}\text { Mean of response } \\
\text { latencies (ms) in } 5 \\
\text { min }\end{array}$ \\
\hline $\begin{array}{l}\text { Hand-eye-Co- } \\
\text { ordination }\end{array}$ & Motor coordination & $\begin{array}{l}\text { Vertical distance from } \\
\text { the set line on the } \\
\text { screen (screen pixels) }\end{array}$ \\
\hline $\begin{array}{l}\text { Symbol Digit } \\
\text { Substitution }\end{array}$ & Coding speed & $\begin{array}{l}\text { Mean of response } \\
\text { latencies (ms) }\end{array}$ \\
\hline $\begin{array}{l}\text { Pattern Com- } \\
\text { parison Test }\end{array}$ & Visual perception & $\begin{array}{l}\text { Number of correctly } \\
\text { matched items }\end{array}$ \\
\hline \multicolumn{3}{|c|}{ Memory and learning tests } \\
\hline Associate Learning & Verbal learning & $\begin{array}{l}\text { Number of correct } \\
\text { responses (three } \\
\text { trials) }\end{array}$ \\
\hline Associate Recall & Intermediate memory & $\begin{array}{l}\text { Number of correct } \\
\text { responses }\end{array}$ \\
\hline Pattern Memory & Visual memory & $\begin{array}{l}\text { Number of correct } \\
\text { responses }\end{array}$ \\
\hline Serial Digit Learning & Learning/memory & Score \\
\hline
\end{tabular}

two bottles of beer (about $0.7 \mathrm{l}$ ) during the previous evening.

During the examination venous blood samples were taken, and the following measurements associated with increased consumption of alcohol were performed (12): gamma glutamyl transferase in serum, aspartate aminotransferase in serum, and the mean cellular volume of erythrocytes. The activty of the two enzymes was analyzed according to the recommendations of the Committee on Enzymes of the Scandinavian Society. The erythrocyte value was determined with the use of an automatic cell counter.

Examination of subjective symptoms. Subjective symptoms were surveyed with the use of the following two methods: (i) a modification of the questionnaire used by Husman (13) and (ii) a computer-administered mood questionnaire included in the psychological test procedure of the Neurobehavioral Evaluation System adapted by Baker \& Letz (14).

On the first questionnaire the answers concerning subjective symptoms $(\mathrm{N}=31)$ had the following three choices: (i) symptom occurs hardly ever (rating 1), (ii) symptom occurs now and then or to some degree (rating 2), and (iii) symptom occurs often or to a disturbing degree (rating 3 ). The following symptom variables were formed and used in the calculations: disturbance of memory (score 2-6), difficulties to concentrate (score $2-6$ ), fatigue (score $2-6$ ), sleep disorders (score 2-6), and tremor of the hands (score 2-6).

The inventory of affects included in the computeradministered test battery is a modification of the profile Mood States (15). One of us ( $\mathrm{HH})$ translated and adapted the items into Finnish. In this inventory 25 items (rating $1-5$ ) were used to get a five-dimensional mood profile called Mood States. The states focused on were tension, depression, anger, fatigue, and confusion (ie, feelings of embarrassment and helplessness). The means of the item scores were used as test parameters in the study.

Psychological test battery. Psychological performances were tested with the Neurobehavioral Evaluation System as adapted by Baker \& Letz (14). The tests and test parameters used in the study are shown in table 1. Every session took place in the same quiet and comfortable room, and the same personal computer equipment was used. The subjects had been informed about the testing method beforehand, and the point had been firmly stressed that the aim of the examination was not to measure general intelligence levels. The motivation of the subjects was evaluated by means of a selfadministered scale, on which the degree of effort in the tests was rated by every subject on a scale from very poor (rating 1 ) to very hard (rating 5 ). The motivation of the subjects was also judged on the basis of observations of their concentration during the session. 
Table 2. Indicators of actual exposure of the study groups.

\begin{tabular}{|c|c|c|c|c|c|c|}
\hline \multirow{2}{*}{ Indicator of exposure } & \multicolumn{3}{|c|}{ Exposed group $(\mathrm{N}=60)$} & \multicolumn{3}{|c|}{ Reference group $(\mathrm{N}=60)$} \\
\hline & Mean & SD & Range & Mean & SD & Range \\
\hline \multicolumn{7}{|l|}{ Blood } \\
\hline $\begin{array}{l}\text { Inorganic mercury }(\mathrm{nmol} / \mathrm{l}) \\
\text { Organic mercury }(\mathrm{nmol} / \mathrm{l}) \\
\text { Total mercury (nmol/l) }\end{array}$ & $\begin{array}{l}33.8 \\
18.1 \\
51.9\end{array}$ & $\begin{array}{r}22.7 \\
9.9 \\
25.0\end{array}$ & $\begin{array}{l}10-130 \\
5-65 \\
15-150\end{array}$ & $\begin{array}{r}4.6 \\
14.3 \\
18.9\end{array}$ & $\begin{array}{l}3.2 \\
8.2 \\
9.2\end{array}$ & $\begin{array}{r}<5-10 \\
5-45 \\
5-50\end{array}$ \\
\hline \multicolumn{7}{|l|}{ Urine } \\
\hline $\begin{array}{l}\text { Mercury ( } \mu \mathrm{mol} / \mathrm{mol} \text { creatinine) } \\
\text { Mercury }(\mathrm{nmol} / \mathrm{l})\end{array}$ & $\begin{array}{l}10.1 \\
84.1\end{array}$ & $\begin{array}{r}6.8 \\
56.6\end{array}$ & $\begin{array}{l}1.9-31.2 \\
15-260\end{array}$ & $\begin{array}{r}1.2 \\
10.0\end{array}$ & $\begin{array}{l}0.9 \\
7.5\end{array}$ & $\begin{array}{c}<0.6-3.8 \\
<5-30\end{array}$ \\
\hline
\end{tabular}

\section{Exposure}

The time-weighted average (TWA) concentration of mercury in blood was computed as an indicator of long-term exposure. Measurements of the blood mercury level covered the period from 1969 until the beginning of the study. The mercury analyses had been performed with the method of Hatch \& Ott (16). Since 1974 the blood mercury levels had been measured with the cold vapor atomic absorption method of Magos $\&$ Cernik (17) modified by Lajunen et al (18). Both the inorganic and organic fractions of mercury were determined with this method, which has been described earlier along with the methods used for quality control (19).

The dose indicators of the actual exposure of the study groups were the inorganic mercury level of the blood, the organic mercury level of the blood, the total mercury level of the blood, and the urinary mercury level. Morning urine samples collected at home on the morning of the examination day were used for the urinary mercury analyses. A venous blood sample $(25 \mathrm{ml})$ was taken during the examination. The polyethylene blood tubes (containing $0.15 \mathrm{ml}$ of heparin, Medica $^{\left({ }^{(}\right)} 5000 \mathrm{U} / \mathrm{ml}$, Finland) and the urine flasks had been analyzed and found to be free of mercury contamination. The modification of Magos \& Cernik (17) was also applied in the analyses of the actual mercury concentration of the blood and urine. The urinary mercury level was corrected for the urinary creatinine concentration according to Jaffe's standard method (20).

\section{Characteristics of the study group}

The individual TWA of the blood mercury concentrations was based on 22 (SD 5.8, range 8-32) measurements. The mean TWA blood mercury concentration of the chlorine-alkali group was 51.3 (SD 15.6, range $24.7-90.0) \mathrm{nmol} / 1$. The mean TWA of the inorganic mercury in the blood was 29.6 (SD 3.3, range 9.8-64.1) $\mathrm{nmol} / \mathrm{l}$, which was based on 19 (SD 4.0, range $8-27$ ) measurements. For 11 exposed subjects the TWA concentration of the organic mercury in the blood exceeded the TWA concentration of the inorganic mercury in the blood.
The figures of the indicators of actual exposure are shown in table 2. Three of the exposed subjects had a blood concentration of organic mercury that was higher than the inorganic fraction. No referent had more inorganic than organic mercury in their blood.

The exposed day workers had significantly higher concentrations of mercury in their blood and urine than the exposed three-shift workers (figure 1). The difference was also seen for the indicators of long-term exposure. The TWA concentration of mercury in the blood of the day workers was 63.3 (SD 13.5, range $37.5-82.4) \mathrm{nmol} / 1$, and that of the three-shift workers was 43.3 (SD 16.5, range $24.7-90.0$ ) $\mathrm{nmol} / 1$.

The exposed and reference workers reported similar average drinking habits (times per week or quantity of intake per time). The cutoff points for the division into subgroups were both the medians of the dose indicators and the form of workshift. The enzyme and erthrocyte measurements did not show any differences between the exposed and reference groups, except for

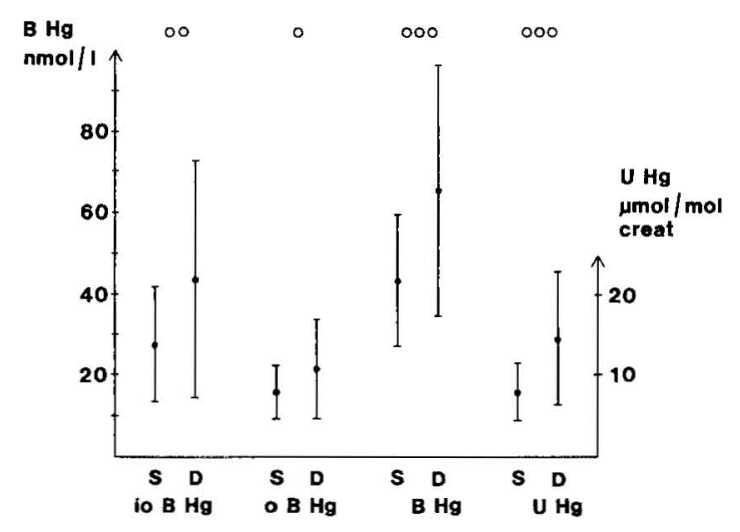

$0 P<0.05 \quad 00 P<0.01 \quad 000 P<0.001$

Figure 1. The means and standard deviations of the actual dose indicators of the exposed subjects grouped into threeshift workers (S) $(N=37)$ and day workers (D) $(N=23)$. The twosided t-test was used for the comparisons between the groups. (io $\mathrm{B} \mathrm{Hg}=$ inorganic mercury level in the blood, $\mathrm{O} B$ $\mathrm{Hg}=$ organic mercury level in the blood, $\mathrm{B} \mathrm{Hg}=$ total level of mercury in the blood, $\mathrm{U} \mathrm{Hg}=$ urinary mercury level) 
Table 3. Comparison of scores for the subjective symptoms between the exposed and reference groups. The paired t-test was used for comparison. (NS = not significant)

\begin{tabular}{|c|c|c|c|c|c|}
\hline \multirow[t]{2}{*}{ Symptom } & \multicolumn{2}{|c|}{$\begin{array}{l}\text { Exposed } \\
\text { group } \\
(\mathrm{N}=60)\end{array}$} & \multicolumn{2}{|c|}{$\begin{array}{c}\text { Reference } \\
\text { group } \\
(\mathbb{N}=60)\end{array}$} & \multirow[t]{2}{*}{ P-value } \\
\hline & Mean & SD & Mean & $S D$ & \\
\hline \multicolumn{6}{|l|}{ Questionnaire } \\
\hline $\begin{array}{l}\text { Memory disturbance } \\
\text { Difficulty to concentrate } \\
\text { Sleep disorders } \\
\text { Tremor of hands }\end{array}$ & $\begin{array}{l}3.47 \\
2.63 \\
3.35 \\
2.38\end{array}$ & $\begin{array}{l}1.24 \\
0.92 \\
1.12 \\
0.83\end{array}$ & $\begin{array}{l}2.58 \\
2.40 \\
2.68 \\
2.15\end{array}$ & $\begin{array}{l}0.83 \\
0.62 \\
0.85 \\
0.48\end{array}$ & $\begin{array}{l}<0.001 \\
\quad N S \\
<0.001 \\
\text { NS }\end{array}$ \\
\hline \multicolumn{6}{|l|}{ Mood scales } \\
\hline $\begin{array}{l}\text { Tension } \\
\text { Depression } \\
\text { Anger } \\
\text { Fatigue } \\
\text { Confusion }\end{array}$ & $\begin{array}{l}2.16 \\
2.11 \\
2.08 \\
2.50 \\
2.02\end{array}$ & $\begin{array}{l}0.75 \\
0.67 \\
0.70 \\
0.73 \\
0.71\end{array}$ & $\begin{array}{l}1.96 \\
1.98 \\
1.83 \\
2.21 \\
1.69\end{array}$ & $\begin{array}{l}0.59 \\
0.41 \\
0.54 \\
0.58 \\
0.58\end{array}$ & $\begin{aligned} & N S \\
& N S \\
&<0.01 \\
&<0.01 \\
&<0.01\end{aligned}$ \\
\hline
\end{tabular}

Table 4. Comparison of scores for subjective symptoms between the exposed workers and their referents grouped according to the form of workshift of the exposed workers. The paired t-test was used for comparison.

\begin{tabular}{|c|c|c|c|c|c|c|}
\hline \multirow{3}{*}{ Symptom } & \multicolumn{6}{|c|}{ Difference in score means } \\
\hline & \multicolumn{3}{|c|}{$\begin{array}{c}\text { Three-shift } \\
\text { workers }(\mathrm{N}=37)\end{array}$} & \multicolumn{3}{|c|}{$\begin{array}{l}\text { Day workers } \\
(\mathrm{N}=23)\end{array}$} \\
\hline & Mean & SD & P-value & Mean & SD & P-value \\
\hline \multicolumn{7}{|l|}{ Questionnaire } \\
\hline $\begin{array}{l}\text { Memory } \\
\text { disturbance }\end{array}$ & 0.5 & 1.4 & $<0.05$ & 1.4 & 1.5 & $<0.001$ \\
\hline $\begin{array}{l}\text { Difficulty to } \\
\text { concentrate }\end{array}$ & 0.2 & 1.3 & NS & 0.2 & 1.0 & NS \\
\hline Sleep disorders & 0.8 & 1.5 & $<0.01$ & 0.5 & 1.3 & NS \\
\hline Tremor of hands & 0.1 & 0.8 & NS & 0.5 & 1.1 & $<0.05$ \\
\hline \multicolumn{7}{|l|}{ Mood scales } \\
\hline Tension & 0.2 & 1.0 & NS & 0.2 & 1.0 & NS \\
\hline Depression & 0.1 & 0.8 & NS & 0.1 & 0.8 & NS \\
\hline Anger & 0.2 & 0.7 & NS & 0.3 & 0.7 & NS \\
\hline Fatigue & 0.3 & 0.8 & $<0.03$ & 0.3 & 0.9 & NS \\
\hline Confusion & 0.3 & 0.7 & $<0.01$ & 0.3 & 0.9 & NS \\
\hline
\end{tabular}

Table 5. Comparison of performances on the psychological tests between the exposed workers and their referents. The paired t-test was used for comparison. The units of measure are shown in table 1. (NS = not significant)

\begin{tabular}{cccc}
\hline \multirow{3}{*}{ Test } & $\begin{array}{c}\text { Exposed } \\
\text { workers } \\
(\mathrm{N}=60)\end{array}$ & & $\begin{array}{c}\text { Referents } \\
(\mathrm{N}=60)\end{array}$ \\
\cline { 2 - 3 } & Mean SD & Mean SD $\mathrm{SD}$ & \\
\hline
\end{tabular}

\section{Psychomotor tests}

Finger Tapping

Preferred hand

Nonpreferred hand

Alternating hands

Continuous Performance

Test

Hand-eye Coordination

Symbol Digit

Substitution

Pattern Comparison

Test

Memory and learning

Associate Learning

Associate Recall

Pattern Memory Test

Serial Digit Learning

\begin{tabular}{rrrrc}
67.4 & 7.1 & 67.3 & 9.1 & NS \\
59.5 & 8.0 & 58.3 & 9.7 & NS \\
49.8 & 7.5 & 48.2 & 9.7 & NS \\
490.6 & 35.2 & 493.5 & 40.7 & NS \\
3.8 & 0.8 & 4.6 & 1.2 & $<0.001$ \\
2.9 & 0.6 & 3.1 & 0.7 & NS \\
14.7 & 0.6 & 14.7 & 0.5 & NS \\
& & & & \\
15.8 & 5.4 & 14.6 & 4.8 & NS \\
5.8 & 2.2 & 5.7 & 2.3 & NS \\
12.2 & 1.6 & 11.7 & 1.9 & NS \\
6.6 & 4.7 & 6.9 & 4.0 & NS \\
\hline
\end{tabular}

one subgroup. The more highly exposed subgroup, whose urinary mercury level was $8.2 \mu \mathrm{mol} / \mathrm{mol}$ of creatinine or more had a higher serum gamma glutamyl transferase level [mean 31.3 (SD 26.5) U/1] and a higher mean cellular volume of erthrocytes [mean 92.8 (SD 3.6) fl] than their referents [gamma glutamyl transferase: mean 21.8 (SD 9.9) U/1; mean cellular volume of erthrocytes: mean 90.9 (SD 4.0) fl], but no difference in the activity of the serum aspartate aminotransferase.

The mean number of teeth with amalgam fillings was 5.0 (SD 5.3, range 0-17) for the exposed workers and 4.5 (SD 5.5, range 0-17) for the reference workers.

All the items of the psychological test battery were performed by every subject. Seven of the exposed workers and 14 of the referents evaluated their degree of effort in the test performances as moderate (rating 3 on the scale $1-5$ ). Two exposed workers but none of the referents evaluated their effort as rather poor (rating 2). All the other subjects had tried hard or very hard (ratings 4 and 5). However, on the basis of the observations made during the sessions, no performances were excluded from the calculations.

\section{Results}

\section{Subjective symptoms}

The exposed workers had systematically more subjective symptoms than their referents (table 3 ). The multivariate analysis of variance of the symptom scores was statistically significant $(\mathrm{F}=3.91, \mathrm{P}<0.001)$. The differences between the exposed and reference groups were highly significant for memory disturbances and sleep disorders. The chlorine-alkali workers also reported significantly more anger, fatigue, and confusion.

To control the confounding effect of three-shift work, we divided the exposed workers into subgroups of three-shift workers and day workers. First, the symptoms of the exposed subgroups were compared with the symptoms of their referents (table 4). Both subgroups reported significantly more disturbances of memory than their referents. Tremor of the hands had been more common in the more highly exposed day worker group. The three-shift workers had more complaints of sleep disorders, fatigue, and confusion than their referents. Second, comparisons between the exposed subgroups showed that the more highly exposed day workers had reported significantly more memory symptoms than the lowly exposed three-shift workers $(t=-3.20, P<0.01)$. A multivariate analysis of variance confirmed the differences between the groups. Third, a two-way analysis of variance was used to detect the dependence of the symptoms of the chlorinealkali workers on exposure, indicated by the blood and urinary mercury levels, and on the form of workshift. According to this analysis the memory disorders were significantly associated with the form of workshift 
$(\mathrm{F}=10.38, \mathrm{P}<0.01)$ but not with the level of exposure. No other significant associations were found between the symptoms, level of exposure, and the form of workshift.

\section{Performances on the psychological tests}

The results of the performances on the psychological tests are shown in table 5. A significant difference between the exposed and reference groups was shown by the multivariate analysis of variance $(F=2.72$, $\mathrm{P}<0.05$ ). Unexpectedly, the performance of the exposed workers on the hand-eye coordination test was significantly better than that of the reference workers, and the exposed workers performed as well as their referents on the other tests. The exposed workers were also grouped according to the medians of the dose indicators (TWA blood mercury concentration 49.1 $\mathrm{nmol} / \mathrm{l}$, inorganic mercury in blood $30 \mathrm{nmol} / \mathrm{l}$, total concentration of mercury in blood $45.0 \mathrm{nmol} / \mathrm{l}$, and urinary mercury concentration $8.2 \mu \mathrm{mol} / \mathrm{mol}$ creatinine) into high and low exposure subgroups, as well as according to the form of workshift. Even so the performances of the exposed subgroups were similar to those of their referents. Furthermore, the test performances of the exposed three-shift workers and the day workers were compared. However, no significant differences were found between the groups. The twoway analysis of variance even showed no significant interactions between the test performances, the level of exposure, and the form of workshift.

\section{Discussion}

In this study the psychomotor, memory, and learning abilities of the exposed workers were similar to those of their matched referents on the psychological tests. The mercury concentration in the blood and urine indicated both a low long-term and a low actual exposure level of the chlorine-alkali workers. Adverse effects on hand steadiness $(5,10)$ and on short-term memory $(6$, 21) have earlier been shown at similar levels of mercury exposure. The selection and motivation of the subjects may have influenced the results of our study however. The workers with low personal hygiene at work, who possibly were uninclined to follow work safety instructions and possibly also had problems with cognitive abilities as well, had been excluded from mercury-exposed tasks. The motivation of the reference group was lower than that of the exposed group, even though all the referents cooperated adequately in the examinations.

The exposed workers complained of more numerous subjective symptoms than did their referents. Similar symptoms have earlier been described in connection with long-term low exposure to mercury vapor (3). In the study of Roels et al (10) the exposure indicated by the blood mercury concentrations was equal to that in our study, and the workers had also had subjective symptoms similar to those of our exposed group, ie, memory disturbances, fatigue, and irritability. In our study the results of the memory tests of the exposed workers did not confirm their subjective memory symptoms, but it should be remembered that tests of learning and memory can never cover all the memory functions needed in everyday life. In the interview the exposed workers described their symptoms as absentmindedness and lapses of memory in small ordinary pursuits. However, one explanation for these reports might be that disturbances of memory had been routinely asked about in the periodic health examinations, and therefore the chlorine-alkali workers might have been guided to emphasize self-observation and perhaps to exaggerate such symptoms. Indeed, the memory symptoms showed a stronger association with the form of workshift (namely, daywork) than with the level of mercury exposure. Strain in the three-shift work was a possible cofactor for the other subjective disturbances, namely, sleep disorders, fatigue, and confusion.

The day workers, whose exposure levels had been higher than those of the three-shift workers, suffered more frequently from unsteadiness of their hands than their referents did. Tremor was well known as an early mercury effect among the chlorine-alkali workers because it had been measured with the aid of drawings made by an unsupported hand during the periodic health examinations performed by the occupational health physicians. In that way the exposed workers were more familiar with the motor tasks, which, together with the lower motivation of the referents on the performance tests, could perhaps explain the significantly poorer performance of the reference subjects in the hand-eye coordination test. The methods used for measuring hand steadiness in our study did not reveal individual parameters of tremor pattern, eg, velocity or the effect of loading on the tremor spectra that were disturbed initially $(5,7,10)$. On the other hand, forearm tremor has been shown to be reversible (12), and the exposed workers had had unsteadiness in their hands only now and then.

The exposed subgroup with the higher urinary mercury level had a higher activity of serum gamma glutamyl transferase and a larger mean volume of erythrocytes than their referents, and this higher value might have been caused by the consumption of alcohol. Earlier, a high excretion of urinary gamma glutamyl transferase, which is richly found in the kidney, has also been connected with a high level of exposure to inorganic mercury $(1,23)$. However, in our study, the subgroup with a higher exposure level to mercury, as indicated by the urinary mercury level, had results similar to those of their matched referents on the performance tests.

In this study no objective disturbances in perceptual motor, memory, or learning abilities were connected with low long-term exposure to elemental mercury vapor, which was estimated (24) to have been about 
on the health-based level for the average long-term mercury vapor concentration in air, ie, $25 \mu \mathrm{g} / \mathrm{m}^{3}$, recommended by the WHO Study Group (4).

Although the exposed workers had subjective symptoms which have earlier been described in connection with micromercurialism, one can conclude that no significant adverse effects were produced by the long-term exposure to mercury vapor at an average mercury concentration of $25 \mu \mathrm{g} / \mathrm{m}^{3}$ of air.

\section{Acknowledgments}

The authors thank Ms I Taipaleenmaki and Ms H Pirkola of the Oulu Regional Institute of Occupational Health for the mercury measurements and Mr P Soini of the Oulu University for the data processing.

This study was supported by The Finnish Work Environment Fund.

\section{References}

1. Berlin M. Mercury. In: Friberg L, Nordberg GF, Vouk VB, ed. Handbook on the toxicology of metals; vol II. 2nd ed. Amsterdam: Elsevier, 1986:387-445.

2. Kark RAP. Clinical and neurochemical aspects of inorganic mercury intoxication. In: Vinken P, Bruyn G, ed. Handbook of clinical neurology; vol 36. New York: Elsevier/North-Holland Biochemical Press, 1979: 147-97.

3. Skerfving S, Vostal J. Symptoms and signs of intoxication. In: Friberg L, Vostal J, ed. Mercury in the environment. Cleveland, Ohio: CRC Press, 1972:93-107.

4. WHO Study Group. Recommended health-based limits in occupational exposure to heavy metals. Geneva: World Health Organization, 1980:106-14. (WHO tech rep ser no 647).

5. Fawer RF, De Ribaupierre Y, Guillemin MP, Berode $M$, Lob M. Measurement of hand tremor induced by industrial exposure to metallic mercury. $\mathrm{Br} \mathbf{J}$ Ind Med 1983;40:204-208.

6. Piikivi L, Hänninen H, Martelin T, Mantere P. Psychological performance and long-term exposure to mercury vapors. Scand J Work Environ Health 1984;10: $35-41$.

7. Roels H, Lauwerys JP, Buchet A, Barthels A, Oversteyns M, Gaussin J. Comparison of renal function and psychomotor performance in workers exposed to elemental mercury. Int Arch Occup Environ Health 1982;50: 77-93.

8. Skerfving S, Berlin M. 59. Oorganiskt kvicksilver: Nor- diska expertgruppen för gränsvärdesdokumentation [Inorganic mercury: Nordic expert group for documentation of occupational exposure limits]. Stockholm: Arbetarskyddverket, 1985. (Arbete och hälsa 20.)

9. Williamson AM, Teo RKC, Sanderson J. Occupational mercury exposure and its consequences for behaviour. Int Arch Occup Environ Health 1982;50:273-86.

10. Roels H, Gennart JP, Lauwerys R, Buchet JP, Malchaire $\mathrm{J}$, Bernard A. Surveillance of workers exposed to mercury vapour: validation of a previously proposed biological threshold limit value for mercury concentration in urine. Am J Ind Med 1985;7:45-71.

11. Schuckmann F. Study of preclinical changes in workers exposed to inorganic mercury in chloralkali plants. Int Arch Occup Environ Health 1979;44:193-200.

12. Shaper AG, Pocock SJ, Ashby D, Walker M, Whitehead TP. Biochemical and haematological response to alcohol intake. Am Clin Biochem 1985;22:50-61.

13. Husman K. Symptoms of car painters with long-term exposure to a mixture of organic solvents. Scand J Work Environ Health 1980;6:19-32.

14. Baker EL, Letz R. Neurobehavioral testing in monitoring hazardous workplace exposures. J Occup Med 1986; 28:987-90.

15. McNair DM, Lorr M, Droppleman LF. EITS manual - profile of mood states. San Diego, California: Educational and Industrial Testing Services, 1971.

16. Hatch WR, Ott WL. Determination of sub-microgram quantities of mercury by atomic absorption spectrophotometry. Anal Chem 1968;40:2085-7.

17. Magos L, Cernik A. A rapid method for estimating mercury in undigested biological samples. $\mathrm{Br} \mathrm{J}$ Ind Med 1969;26: 144-9.

18. Lajunen L, Kinnunen A, Yrjänheikki E. Determination of mercury in blood and fish samples by cold-vapor atomic absorption and direct current plasma emission spectrometry. At Spectrosc 1985;6:49-52.

19. Piikivi L, Ruokonen A. Renal function and long-term low mercury vapor exposure. Arch Environ Health (in press).

20. Chasson AL, Grady HT, Stanley MA. First order kinetic method. Am J Clin Pathol 1961;35:83-8.

21. Schiele R, Schaller KH, Grobe T. Untersuchungen an beruflich Quecksilberexponierten Personen. Arbeitsmed Sozialmed Präventivmed 1979;10:226-9.

22. Miller J, Chaffin DB, Smith RG. Subclinical psychomotor and neuromuscular changes in workers exposed to inorganic mercury. Am Ind Hyg Assoc J 1975;36: $725-33$.

23. Stonard MD, Chater BV, Duffield DP, Nevitt AL, O'Sullivan J J, Steel GT. An evaluation of renal function in workers occupationally exposed to mercury vapour. Int Arch Environ Health 1983;52:177-89.

24. Roels H, Abdeladim S, Ceulemans E, Lauwerys R. Relationships between the concentrations of mercury in air and in blood or urine in workers exposed to mercury vapour. Ann Occup Hyg 1987;31:135-45.

Received for publication: 16 May 1988 